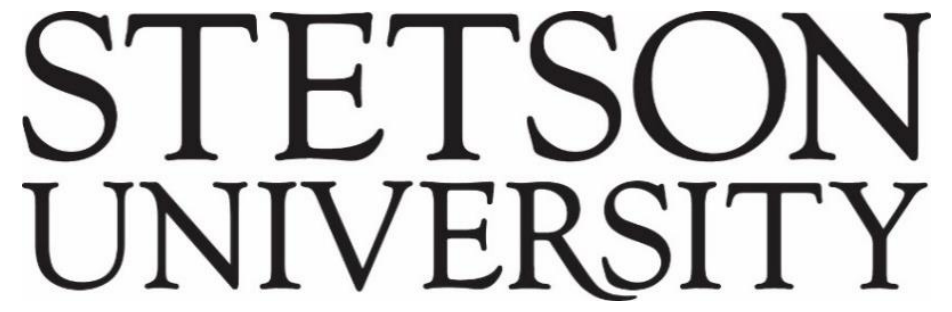

Voices of Reform: Educational Research to Inform and Reform

Volume $2 \bullet$ Issue $1 \bullet$ Article 5

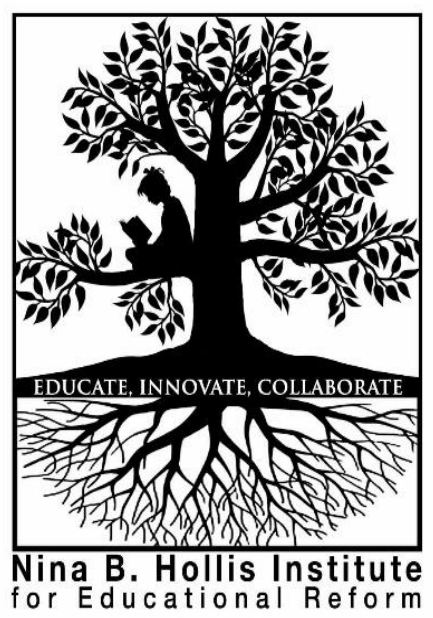

September 2019

\title{
Teaching Asian-American Literature and American Multiculturalism in Singapore
}

Hyo Kyung Woo

Boston University

Follow this and additional works at: http://www.voicesofreform.com

Recommended Citation

Woo, H. (2019). Teaching Asian-American literature and American multiculturalism in Singapore. Voices of Reform, 2(1), 73-86. Retrieved from https://www.voicesofreform.com/article/10612-teaching-asian-americanliterature-and-american-multiculturalism-in-singapore doi: 10.32623/2.00007

http://dx.doi.org/10.32623/2.00007

Revisions

Submission date: March $14^{\text {th }}, 2019$

$1^{\text {st }}$ Revision: May $17^{\text {th }}, 2019$

Acceptance: June 2 $2^{\text {nd }}, 2019$

Publication date: September $30^{\text {th }}, 2019$ 


\title{
Teaching Asian-American Literature and American Multiculturalism in Singapore
}

\author{
Hyo Kyung Woo ${ }^{1}$ \\ ${ }^{1}$ Lecturer \\ Department of English \\ Boston University, United States \\ hkwoo@bu.edu
}

\begin{abstract}
This article examines the implications of teaching Asian American literature and American multiculturalism in Singapore. Using the multicultural and multilingual city-state of Singapore as a case study, I share the challenges and difficulties I experienced as an international teacher in my attempt to translate U.S. ethnic studies into a Singaporean classroom. The essay narrates how local Singaporean students conceptualize and understand U.S.-based multiculturalism and ethnic formation in relation to their own local experiences. Given that Chinese are the major ethnic group in Singapore, I observed how my students responded to Chinese exclusions in U.S. history and applied their findings to the history of Chinese Singaporeans and their relationships with other ethnic minorities in Singapore, such as Malay and Indian Singaporeans. This essay also describes a group assignment I designed asking students to visit five ethnic enclaves in Singapore after reading and discussing Asian American literature about a Chinatown in class. By performing this group work, my students critically compared and contrasted different ethnic settings, histories, and formations between the U.S. and Singapore. This essay ultimately argues that transnational pedagogy of ethnic studies can nourish the creation of alternative imaginaries by using literature to teach students to engage more fully with a different culture.
\end{abstract}

\section{Keywords}

higher education, Asian-American literature, transnational pedagogy, Singapore

\section{Overview}

Over recent years, higher educational institutions have become increasingly globalized. Some institutions create a partnership with institutions in another country, while some establish branch campuses in other countries. And higher educational institutions in the United States are one of the most distinctive forces in the globalization of education. C. Bovilla, L. Jordan, and N. Watters (2015) argue that "calls for internationalization" are often responding to "national and global 
pressures to maximize knowledge transfer, where knowledge is viewed as a global commodity" (p. 13). Alongside the significant movement of students internationally, teachers are also increasingly moving between different international settings for their research and teaching opportunities. I had an opportunity to teach students in Singapore for two semesters as a postdoctoral fellow at Nanyang Technological University in Singapore. Teaching in Southeast Asia was a very different experience for me, a Korean national who trained as ethnic literary studies scholar in the U.S. This experience gave me an opportunity to contemplate the difficulties of teaching Asian American literature in a transnational, cross-cultural context. In particular, the experience prompted me to explore the relationship between the local and the global, or the intertwining of the two.

\section{Literature Review}

Gloria Ladson-Billings' (1995) ground-breaking work of "culturally relevant pedagogy" has a strong impact on education programs in the United States. In her studies of African American students in an urban setting, she argues that teachers should provide meaningful educational experiences to "help students to accept and affirm their cultural identity while developing critical perspectives that challenge inequities that schools (and other institutions) perpetuate" (p. 472). This culturally relevant pedagogy thus challenged previous scholarship defining minority students in deficit terms and supported cultural competence and critical consciousness of students (p. 483). Ladson-Billings suggested that culturally responsive pedagogy encompasses three components: 1) high expectations for students' academic success, 2) development and maintenance of cultural competence, and 3) development of critical or sociopolitical consciousness. Culturally relevant pedagogy was echoed in many education studies in the context of U.S. multicultural education including William F. Tate IV (1997), Laurence Parker (1999), Daniel G. Solórzano (2002), and D. Paris (2012), to examine a range of educational issues regarding race and racism and to sustain the cultural and linguistic competence of students from minority communities.

In addition, Geneva Gay (2000) suggests the term "culturally responsive teaching" (CRT), a multicultural pedagogy "using the cultural knowledge, prior experiences, frames of reference, and performance styles of ethnically diverse students to make learning encounters more relevant to and effective for them" (p. 31). Her approach in particular focuses on the responsibility of teachers to practice culturally responsive teaching. She identifies six characteristics of culturally responsive teaching as follows: 1) culturally validating, 2) comprehensive, 3) multidimensional, 4) empowering, 5) transformative, and 6) emancipatory (pp. 31-38). This methodology points to teachers' ability to serve as cultural organizers in their classrooms, stimulating minority students to acknowledge their cultural heritages and their sense of belonging. Both Ladson-Billings and Gay assumes the classroom a place for social change by reinterpreting the political implication of minority culture as a valuable pedagogical source.

Echoing both Ladson-Billings and Gay, a wide range of Asian American studies teachers sought to bring value to the Asian American voices of those typically ignored in a society steeped in racism. Kenyon Chan (2000), for example, has emphasized the importance of community in Asian American Studies since the 1960s social movement for diversifying higher education and curriculum in U.S. Asian American studies, both as academic research and activism, strongly 
supported the empowerment of minority community. She proposed to redefine teaching and pedagogy as a commitment to the Asian American community where students find a way to narrate their marginalized experiences in a classroom. Culturally relevant pedagogy, in this sense, gives more power to the voice of Asian American students struggling to understand their cultural heritage and challenge the complexities of racism in society.

Culturally relevant pedagogy historically has been developed in the context of U.S. multiculturalism and ethnic/racial politics. However, it provokes some questions when it is applied to a transnational context, where the dominant student body is not Americans. On one hand, it comes in line with postcolonial pedagogy seeking to oppose a Eurocentric curriculum that excluded and denigrated the experiences of non-Western countries. On the other hand, it still begs the question of the definition of relevant culture when American texts travel from the U.S. to somewhere else. As Django Paris (2012) rightly points out, static conception of cultural relevance might not work in many rapidly changing and evolving classrooms around the world. It is a challenging task for a transnational teacher to define and practice a culturally relevant pedagogy in her classroom. Given that many higher educational institutions accelerate globalization of the educational process, Asian American studies outside of the U.S. aim to broaden the curriculum to include local histories, cultures, and heritage in relation to critical analysis of the global dimensions of U.S. racism and imperialism.

Asian American studies teachers outside of the U.S. have sought to develop transnational teaching strategies that affect social change in local classrooms. A wide range of overseas Asian American literature teachers began to share their experiences of teaching, asking what happens when Asian American literary texts travel from the United States to Asia. These narratives are meaningful, especially when U.S. educational institutions establish regional branches around the world while many non-U.S. higher educational institutions accept the U.S. educational system and curriculums in general.

In this regard, some Asian Americanists express their concerns with and rewards of the global education of Asian American studies. King-Kok Cheung, an Asian American Studies scholar at UCLA who spent a significant time teaching American literature outside the U.S., wrote in "Pedagogies of Resonance" (2004) her experience of teaching Asian American literature in Asia. According to her, Asian American literature speaks to an Asian audience in some unexpected ways that deal with race and ethnicity and contributes new readings of American literature. Grice (2009) also shared her narrative of teaching Asian American history in Europe to illustrate how her students responded to Asian American history and racial issues across the Atlantic. These case studies reveal the difficulty of translating American cultural forms into local problems of their own involvement and approach, which sometimes deal with a lack of cultural specificity and context.

Recent educational panels and forums regarding translational Asian American pedagogy are a useful venue to share collective experiences of overseas teachers spread around different locations. These case studies constantly point out how teachers make their transnational teaching experience culturally relevant to the society they are located in. Lawrence-Minh Bui Davis, panel organizer and editor of the 2012 "Forum: On Teaching Asian American Literature Outside of the U.S," explains that there is "a considerable and growing roster of professors across the world teaching 
Asian American literature. The 'field' is burgeoning, and it has much to tell us about Asian American literature as a body of work, as a subject of inquiry, as a node, as a window onto transnational realities we at once study and bring into being" (p. 6). In the volume, teachers from Taiwan, South Korea, and China share the historical background of when Asian American literature was introduced and their lively experience of teaching at universities. By teaching Asian American literature, these teachers aim to recast the notion of Asia as a critical idea haunted by interconnected histories and movement across national borders. For example, Feng (2009) explored the historical importance of multicultural and multiethnic studies in Taiwan, considering Taiwan's specific ethnic composition and relationship to mainland China. She argued that the multiethnic stratification of Taiwan makes the study of Asian American literature "highly relevant to the local sociopolitical reality" (p. 7). Hyungji Park (2009) claims that Korean American literature is relevant to help his students at Yonsei University to understand South Korea's historically constructed racism and diasporic history outside Korea.

Over the years, Asian American studies scholars in Singapore also have participated in sharing their classroom experiences and pedagogical concerns. For instance, de Souza (1996), claims the importance of teaching Asian American literature in Singapore because it could diversify English literature curriculum in Singapore that used to focus on British canons (p. 2). He urges Singaporean teachers and education officials to take into consideration the need for literature syllabuses which are relevant to the Singaporean context. For instance, the strong representation of the Asian community in Asian American literature can parallel with life in Singapore where traditional Asian values and Western culture clash against each other (p. 7). Lim (2008) also emphasizes the potential benefit of teaching Asian American literature in Singapore as a vehicle to challenge the hegemony of the colonial Anglophone canon in an English curriculum. Asian American literature attributes local students to the development of critical awareness about multicultural realities in Singapore (p. 144). Both scholars believe that Asian American literature education can provide useful lessons to deal with racial and ethnic issues in Singapore.

In dialogue with previous scholarships, this essay aims to revisit my teaching experience in Singapore, a multicultural and multilingual city-state where the current population descends from various migrations since their political independence in 1965. Singapore displays a different multicultural formation than the U.S. due to its Chinese-dominated heritage. It is then important to consider how one case of a multiethnic country can benefit another despite their geopolitical differences. I would like to share more specific teaching narratives including student responses and their group activity assignment as a way to bring a new dimension of contextualizing the locality within a global discourse.

\section{Local Classroom in a Transnational Setting: The Case of Singapore}

Singapore is one of the most ethnically complex nations in the world. It consists of four racial categories called CMIO (Chinese Malay, Indian, Others) where 75 percent are ethnic Chinese, 17 percent are ethnic Malays, 7 percent are ethnic Indians, and the rest are classified as Others. In education, every student must learn, in addition to English, his or her so-called mother tongue: Mandarin Malay, or Indian languages based on their racial group. Thus, race is a highly visible factor in both the public and private sphere in Singapore (Huat, 2003, p. 65). 
Nanyang Technological University is a rapidly growing young university in Singapore. Even though higher educational institutions in Singapore used to adopt the British educational system in general, the university was in the process of accepting more Americanized curriculums and hired faculty members who completed $\mathrm{Ph}$. D programs at U.S. universities to increase its competency on a global scale. My course HL 9027 Asian American Culture and Transpacific Imaginations mainly opened to juniors and seniors as well as freshmen and sophomores who wanted to fulfill a general elective requirement. The course drew students from all disciplines, including engineering, business, humanities, social sciences, and education. I was the sole instructor for the course.

My course took place during the 2016 campaign for the United States Presidential Election and Singaporean local news was reporting on this campaign every day. During my initial class, I decided to spend the first thirty minutes watching Donald Trump's speech on Mexican borders and the Chinese as a potential threat to the country and had a short discussion following his speech. After watching two short speech video clips on YouTube, I asked students if they noticed anything common in Trump's use of language. In a class of forty-five, students began to share their findings of how Trump constantly uses terms as "we" versus "they" while demonizing both Chinese and Mexicans as the undesirable others. I also asked students how this kind of attitude and rhetoric would affect their everyday life in Singapore, which most students could not make any clear connection to except a vague answer to criticize racism in general. At this moment, I shared my course objectives that we would critically examine Asian American literature in two ways: 1) how it domestically plays the role of an imaginative other that constantly challenges and reconstructs the core identity of America, and 2) how it transnationally relates to the experiences of migrations, war, imperialism, and globalization in Asia-Pacific regions including Singapore.

In terms of student demographics, teaching Asian American literature to Singaporean students was a very different experience in comparison to my previous teaching experiences. Before I moved to Singapore, I taught multiethnic literature or postcolonial literature at the University of Pittsburgh. While the majority of my students in Pittsburgh were Caucasians who had seldom been exposed to Asian American issues, they experienced some Asian culture by eating Chinese or Thai food in local restaurants and watching anime or martial arts movies. Therefore, they had some abstract ideas of Asia, but not Asian Americans. Most students were monolinguals who explicitly speak and write only in English. In contrast, in Singapore 37 students out of 45 were bilinguals, speaking at least two languages every day. ${ }^{1}$

Even though English is the lingua franca of the majority, English is still a privileged cultural capital in Singapore. A weakness in English language skill indicates the economic disadvantages of students. Children from non-English speaking families tend to speak locally known "Singlish."2

\footnotetext{
${ }^{1}$ In Singapore, English is the first language taught in most schools, with a choice of Mandarin, Malay, and Tamil as second languages based on their family heritage. The learning of two languages is mandatory because it is considered "important to counterbalance the Westernizing impact of English through access to Asian cultural roots via the mother tongue" (Siddique, 1990, p. 37). The bilingual education system reinforces students to build a strong tie to their heritage and language.

${ }^{2}$ According to Huat (2003), Singlish contains many exclamation sounds, such as "lah," "mea," and "loh" derived from Chinese dialect sentences, particularly Hokkien (p. 73).
} 
In my classroom, I noticed that English used by my students varied based on their formal education or family background; some used British-accented English or American-accented English. These students may have been educated in prestigious private schools run by foreign institutions, whereas the majority of students whom attended public schools used Singlish. Therefore, the hierarchy of English as a colonial legacy is vividly present in contemporary Singapore. This linguistic social structure helped me to teach the language issue in Asian American literature, such as how accented English is considered a marker of immigrant status as unassimilable aliens. In this light, my students sympathized with Chang-Rae Lee's Native Speaker (1995) where standard English indicates the authentic identity of true American. I also could feel less pressure of being a young, female teacher who speaks accented English in Singapore than in the U.S., where my authority as an English literature teacher was constantly challenged in student surveys.

It was relatively easy for my students to understand the theoretical concerns of Asian American literature when many of them were also descendants of Asian immigrants and have relatives overseas. Based on the in-class survey, my students seemed to find this course more generally accessible and easy to voice their opinions than other canonical English courses. This partially stems from what Walter S. H. Lim (2008) called "the shared affinities" between Asian American culture and Singaporean culture (p. 140). My students were critically engaged with the issue of the Chinese Exclusion Act or the Japanese Internment during World War II which highlighted statesanctioned mistreatment against Asian immigrants.

Students tended to engage with the class theme more actively when I was able to incorporate the situation of Singapore into the Asian American context for comparison. For instance, when we were studying the 19th-century representation of Chinese workers in the U.S. under the Chinese Exclusion Act in 1882, the concept of "permanent alien" constantly appeared in the primary texts. Many Americans believed that the Chinese were not able to fully assimilate into American society because of their distinctive ethnic features in language, food, and clothing. My students criticized this unfair stereotyping to justify the eviction of the Chinese from the U.S. and to deprive them of the opportunity to naturalize. A number of historical documents and public discourses have implied that the Chinese were considered inassimilable to American society, and I wonder how my students would respond to such an accusation. At this moment, I joked about the many exchange student groups at Nanyang Technological University, comprised of mainly Caucasian students from Europe or the U.S., are always enjoying their Friday nights at outdoor tables at one of the school cafeterias. I told my students every time I passed them by, I've never seen one single Singaporean student mingle with them. We shared a good laugh over "inassimilable whites" to point out the ideology of assimilation becomes a real problem when the minority group is involved. In the following moment, my students began to share their experiences of racism in their own society. For example, one student pointed out that white faces always appear in commercials and TV advertisements to attract customers to luxurious hotels and resort in Singapore. Other students also pointed out expensive designer brand shops commonly adopt Caucasian models rather than local ones.

As my anecdotes imply, I wanted students to critically explore and actively engage with their surroundings based on what they learned in Asian American literature. When I started teaching in 
Singapore, some colleagues told me that Singaporean students are too docile and quiet, and it would be hard to expect them to talk in class. To the contrary, I found my students to be willing to engage with critical perspectives of Asian American culture because they "resonated with them personally in a way that canonical British and American literature did not" (Cheung, 2004, p. 253).

However, the challenge started when I attempted to gear my students' attention to the internal racism within their own society. Although students were good at grappling with white privilege and racism against people of color, it was hard for them to see racial and ethnic conflicts between Asians. My students readily empathized with Asian American characters in the texts whom were often victims of unjust treatment and racial profiling, yet they had a hard time to see themselves as a dominant group. Discriminatory ideologues behind the Chinese Exclusion law in the U.S. did not easily transfer to that of Singapore where the government carefully manages the unstable status of non-Singaporean immigrants. Rather, the majority of students saw their country as a harmonious and happy multicultural place in which CMIO peacefully co-exist, unlike western countries. They did not see racism in their everyday lives, except a few who strongly disagreed with such representation.

On the contrary, I often saw Malaysian construction workers filing into the back of an open-air truck without any air conditioning, or young Filipino maids spending their weekends sitting on stairs on Orchard Street (shopping district) all day because their owners did not like them to stay at home on weekends. According to Huat's study of the racial formation of Singapore (2003), a fourth of the population consists of 750,000 foreign workers in this global hub-city. These foreign workers are divided into two categories, professionals and guest workers. Unlike professionals, such as university professors, doctors, and engineers, who earn a high salary and have job security, guest workers are unskilled workers from neighboring countries, mainly construction workers or domestic workers. These guest workers are not allowed to marry any locals, otherwise, they will be deported.

Another challenge lies when Singapore students tend to strongly approve of the myth of the Asian American model minority in their everyday practices. ${ }^{3}$ Pin-chia Feng (2009) described that she was challenged by Taiwanese students who kept asking what's wrong with being a model minority. This tendency became more apparent in economically developed countries, including Hong Kong, Singapore, South Korea, and Taiwan, where economic success was gained under strong government leadership to make people deny "the presence of systemic inequality and privileges successful people of color" (Schlund-Vials, 2011, p. 108). My students often adopt what Christopher Doob (2013) called "the colorblind racism" assumption that racism no longer exists in Singapore between Asians. Thus, it was a challenging task for me to help students to see the racial hierarchy between inter-Asian groups when racism is considered some individual deviation rather than an institutional problem. The model minority myth my students embodied reaffirmed that Asian American studies could be relevant in contemporary Singapore.

\footnotetext{
${ }^{3}$ In 1960s, it was the U.S. News and World Report that came up with the term "model minority." It argued, "At a time when Americans are awash with worry over the plight of racial minorities — one such minority, the nation's 300,000 Chinese-Americans, is winning wealth and respect by dint of its own hard work" (Success Story of One Minority Group in the US, 1966).
} 
The final challenge I encountered in the classroom was my position as an outsider and teacher. Neither Singaporean nor American, I took advantage of this in-between position as an instructor of ethnic studies, but I also had to be cautious when I made comments on Singapore and local people that I did not have much knowledge about. Therefore, drawing a proper line between pushing my students to recognize their own society and being a rude foreigner was complicated. From one perspective, I was impressed by the openness and generosity of my students. Additionally, I witnessed the logic of racial harmony enforced on people in a country dominated by a single authoritarian party. The call for culturally relevant pedagogy in the study of Asian Americans places pressures on the preparation of faculty. This was the moment I felt that there was a missing part of local life that I could not fill up for my students. So, I let my students speak for themselves.

\section{Exploring the Local: Ethnic Enclave Group Work}

To encourage my students to speak about their community, I decided to include my students' local communities in their project work. I designed a group assignment including community-focused research, the Singapore Ethnic Enclave Group Project. This assignment was designed to compare the U.S. ethnic enclaves we studied in the classroom to the ones in Singapore. The assignment included field research in several ethnic enclaves in Singapore, historically occupied by different ethnic groups throughout its complex colonial history. I proposed five ethnic enclaves around Singapore as research objects: Chinatown, Little India, Kampong Glam (Arab Street), Geylang (Muslim Malay Enclave), and Tanjong Pagar (Koreatown). Each group consisted of 5 to 6 students based on their choice. Some students chose an ethnic enclave based on their heritage and family background, while others chose an ethnic enclave they never visited or unrelated to new findings.

Once each group was assigned, students created a specific research topic and wrote a proposal to outline their plan together. I was pleased to see the diverse topics my students came up with and their insightful ideas. The range of topics included the ethnic food culture in the Malay ethnic enclave, the gentrification of Arab Street into an ethnic shopping site, the ethnic diversity of Little India, and Koreatown as a new emerging business ethnic enclave. These proposals in common paid attention to the contemporary formation of ethnic enclaves. They were interested in how the traditional identity of the ethnic enclave has been translated into contemporary Singapore in terms of ethnic tourism, global capitalism, and consumer culture.

I would like to introduce one student group's work about Chinese temples in Singapore's Chinatown in this paper. This group wanted to investigate different temples in Chinatown, such as Thian Hock Temple, Buddha Tooth Relic Temple, the Sri Mariamman Temple, Masjid Jamae, Masjid Al-Abrar, and Nagore Durgha. In their proposal, students wrote:

It is not surprising to see Chinese temples in the Chinese enclave of Singapore, but what is more interesting to see is the religious sites of other ethnicities located in the Chinese enclave. These religious sites of other ethnic were built in the early 19th century, which coincide with the period where the first wave of Chinese Coolies influx reached its peak. The aim of our research is to find out how religious sites of different ethnicities could assimilate and create a harmonious picture with the Chinese temples in the olden days Chinatown. 
What I found most promising about this proposal was that my students linked Chinese temples as a source to build Chinese ethnic identity and paid attention to the unique multi-ethnic formation of the Chinatown in Singapore. In other words, they pointed out that Chinatown as an ethnic enclave is not a homogenous, essentialist entity that only Chinese-related products or sites exist. Instead, they drew attention to the non-Chinese hybrid aspects of the Chinatown (where a Muslim mosque and a Hindi temple neighbor a Buddhist temple), which is one of the distinctive features of Singapore's Chinatown. The Asian American primary texts I provided in the classroom did not show such ethnic blending, nor did I mention this fact. Therefore, my students were independently able to find their own critical engagement with their local community. I was quite interested to see how my students would critically develop and examine their initial view on the ethnic formation of the Chinatown as "assimilation" and "harmonious picture" throughout their research.

To help my students conduct their research more efficiently, I divided the assignment into three consecutive sectors: 1) historical research, 2) on-site research, and 3) comparative research. The historical research was preparation before onsite research where students investigated the historical background of their ethnic enclaves. Students used various sources, such as books, magazines, and digital archives, investigated the historical background of their ethnic enclave. The Chinatown group began their investigation from the historic moments that each temple was constructed. They found that Chinatown was originally known for its opium-smoking dens and stations for coolie trade in the 1800 s to the 1850 s, and later became a retail trade place for textile and tailor shops. Students researched each temple in the Chinatown chronologically, starting from Sri Mariamman Temple built in 1827 by South Indian immigrants, the Al-Abrar Mosque in 1827 by Chulias, to the Thian Hock Keng Temple by Hokkien Chinese immigrants in 1839. Exploring the history of temples in the Chinatown district allowed students to see the overlapping colonial and migration history of Singapore where multiple ethnic identities have co-existed, yet the name "Chinatown" in the region implies the current dominance of Chinese heritage over another ethnicity.

In the fieldwork report, students confirmed or revised their historical findings that Chinatown includes "different cultures from Thai restaurants to a Hindu worship place on the same street of Chinese influence." The group, through their participatory observation and interviews with locals, found out that the Chinese temple founded by the Hokkien clan association served as a social place for people with the same Chinese dialects and provided Chinese education for children. In their ethnographic essay, they wrote that the Chinese temple was favored by Chinese immigrants heading back to China to pray for calm waves and a safe journey. At this stage, my students examined the ethnic enclave, not only as a geographical territory but also a cultural embodiment of ethnicity. They explored the complicated social relations of Chinatown residents by combining historical, literary, and social science perspectives.

I was curious to see how my students critically developed their original premise of cultural hybridity of the Chinatown in Singapore in their final report, and the result came with both reward and limit. I asked my students to explain the conclusion of their research in comparison to ethnic enclaves in the U.S. Admittedly, there was a certain limitation in researching ethnic enclaves in the U.S. from a distance. But I wanted to build a bridge between Asian American studies and Singapore so that students are more likely to engage with their cultural context. The group 
successfully pointed out the unique inter-Asian relationship in Singapore's Chinatown based on the representation of temples with different religious origins. They then compared this hybrid cultural form of Singapore's Chinatown to San Francisco's Chinatown that demonstrates more China-centered arrangements. The group interpreted Singapore's Chinatown as a positive and open characteristic. However, the report did not demonstrate the in-depth analysis of the ideological aspect of such hybridity as a result of multiple colonial histories and the governmental policy on controlling ethnic residency under the name of harmonious multicultural Singapore.

In short, the purpose of this assignment, despite some limitations, was to develop a new understanding of the ethnic community in their neighborhoods through research and direct field work. This experimental assignment provided my students with an opportunity to cultivate a certain degree of self-awareness of their own society in a transnational learning environment.

\section{Implications and Recommendations}

I believe that Asian American studies courses should develop critical consciousness (Freire 2005) that enables students to situate themselves within a broader understanding of the Asian experience in a globally interconnected world. Therefore, teaching Asian American studies outside the U.S. encompasses the combination of transnational and local dimensions. By looking into the multidimensional dynamics of oppression and systematic violence in Asian American literature, my students in Singapore had an opportunity to see how their individual experiences intersect with larger social, cultural, and political forces. Based on my experience, I would like to make three recommendations for Asian American studies and ethnic studies teachers who teach outside the U.S.

Recommendation 1: Asian American studies teachers should provide an opportunity for students to encompass their local cultures and heritage as a form of culturally responsive teaching. Although ethnic studies teachers in a transnational setting can play a major role in improving multiethnic sensibility and knowledge among local students, teachers alone cannot implement the changes across systems. The involvement of many more students will be necessary to make and sustain social changes in the region.

Recommendation 2: Comparative activities for exploring local culture should be made accessible to all students. Ethnic studies have emphasized the importance of connecting academia and community. Teachers should advocate for an activity that fosters students' awareness of their own culture in addition to Asian American culture discussed in the classroom. The cultural gap between a teacher and students could possibly open up a space to discuss and compare different cultures that can be beneficial to students by allowing them to reconsider their local communities as academic resources.

Recommendation 3: Asian American studies teachers should challenge local students' notions of racism in their own society by calling attention to subtle and invisible racism among the locals. Culturally responsive teachers should consider their classroom as a site for social change, especially emancipatory and liberating place for students, in addition to academic achievement. In this context, students should be trained to consider multilayered and complicated aspects of their own society by positioning them both as a victim and beneficiary of racism. 
To this end, the use of local materials such as ethnic enclaves, in my experience, was particularly effective in helping students to think about complex Asian experiences both on a global and local scale. Building independent research projects became another way to develop links between the course and their everyday lives. Teaching Asian American literature in Singapore also made me revisit my pedagogy as a teacher in a transnational classroom by reflecting how we teachers can reshape higher education that provides a more culturally relevant learning experience to unimaginably different student groups around the world.

Teaching American multiculturalism in an unfamiliar setting allowed me to see how the local students themselves could play a vital role in bridging the gap between knowledge acquired in the classroom and knowledge acquired in local society. Ethnic studies teachers who teach at an overseas institution must realize that as an outsider, their expertise will be limited in an attempt to decide what is culturally relevant. This limitation, however, does not necessarily mean pedagogical failure. My lack of local specificity became an invitation for my students to open up a place where students contributed their narratives. When they saw a teacher seeking their help to explore local culture and communities, I could earn their trust enough to push them to see internal racism and ethnic conflicts existing in the local context. Utilizing local sources, albeit burdensome to a foreign teacher, is still a significant and effective way to encourage students to channel their learning into their community as well as an opportunity for a teacher to understand students' cultural heritage more. This constant engagement with the local community will show us how a critical pedagogy of American multiethnic studies should develop a culturally relevant education for a diverse group of students in the age of globalization.

\section{References}

Bovill, C., Jordan, L., \& Watters, N. (2015). Transnational approaches to teaching and learning in higher education: Challenges and possible guiding principles. Teaching in Higher Education, 20(1), 12-23.

Chan, K. S. (2000). Rethinking the Asian American studies project: Bridging the divide between campus and community. Journal of Asian American Studies, 3(1), 17-36.

Cheung, K. K. (1990). Reflections on teaching literature by American Women of Color. Pacific Coast Philology, 25(1/2), 19-23.

Cheung, K. K. (2004). Pedagogies of resonance: Teaching African American and Asian American literature and culture in Asia. In Brada-Williams, N. \& Chow, K. (Eds.), Crossing Oceans: Reconfiguring American Literary Studies in The Pacific Rim (13-28). Hong Kong, CN: Hong Kong University Press.

Doob, C. (2015). Social inequality and social stratification in US society. New York, NY: Routledge.

De Souza, D. (1996). Asian American fiction and the literature curriculum in Singapore. Singapore: National Institution of Education.

Feng, P. C. (2009). Teaching Bone: A Taiwanese perspective. American Book Review, 31(1), 7-8.

Freire, P. (2005). Pedagogy of the oppressed. New York, NY: Bloomsbury Publishing USA.

Gay, G. (2000). Culturally responsive teaching: Theory, research, \& practice. New York, NY: Teachers College Press.

Grice, H. (2009). Teaching Asian America in Europe: Race, Pedagogy, and Inter-Cultural Engagement. American Book Review, 31(1), 10-11.

Huat, C. B. (2003). Multiculturalism in Singapore: An instrument of social control. Race \& Class, 44(3), 58-77.

Ladson-Billings, G. (1995). Toward a theory of culturally relevant pedagogy. American Educational Research Journal, 32(3), 465-491.

Lawrence-Minh Bui Davis Forum: On Teaching Asian American Literature Outside of the U.S. The Asian American Literary Review (2012): 6. 
Lim, W. S. (2008). Some musings on cultural responses to Asian American literature in Singapore. Amerasia Journal, 34(2), 137-144.

Paris, D. (2012). Culturally sustaining pedagogy: A needed change in stance, terminology, and practice. Educational researcher, 41(3), 93-97.

Park, H. (2009). The immigrant as spy. American Book Review, 31(1), 8-9.

Schlund-Vials, C. J. (2011). Re-seeing race in a post-Obama age: Asian American studies, comparative ethnic studies, and intersectional pedagogies. New Directions for Teaching and Learning, 2011(125), 101-109.

Siddique, S. (1990). The phenomenology of ethnicity: A Singapore case-study. Sojourn: Journal of Social Issues in Southeast Asia, 35-62. 


\section{Appendix A}

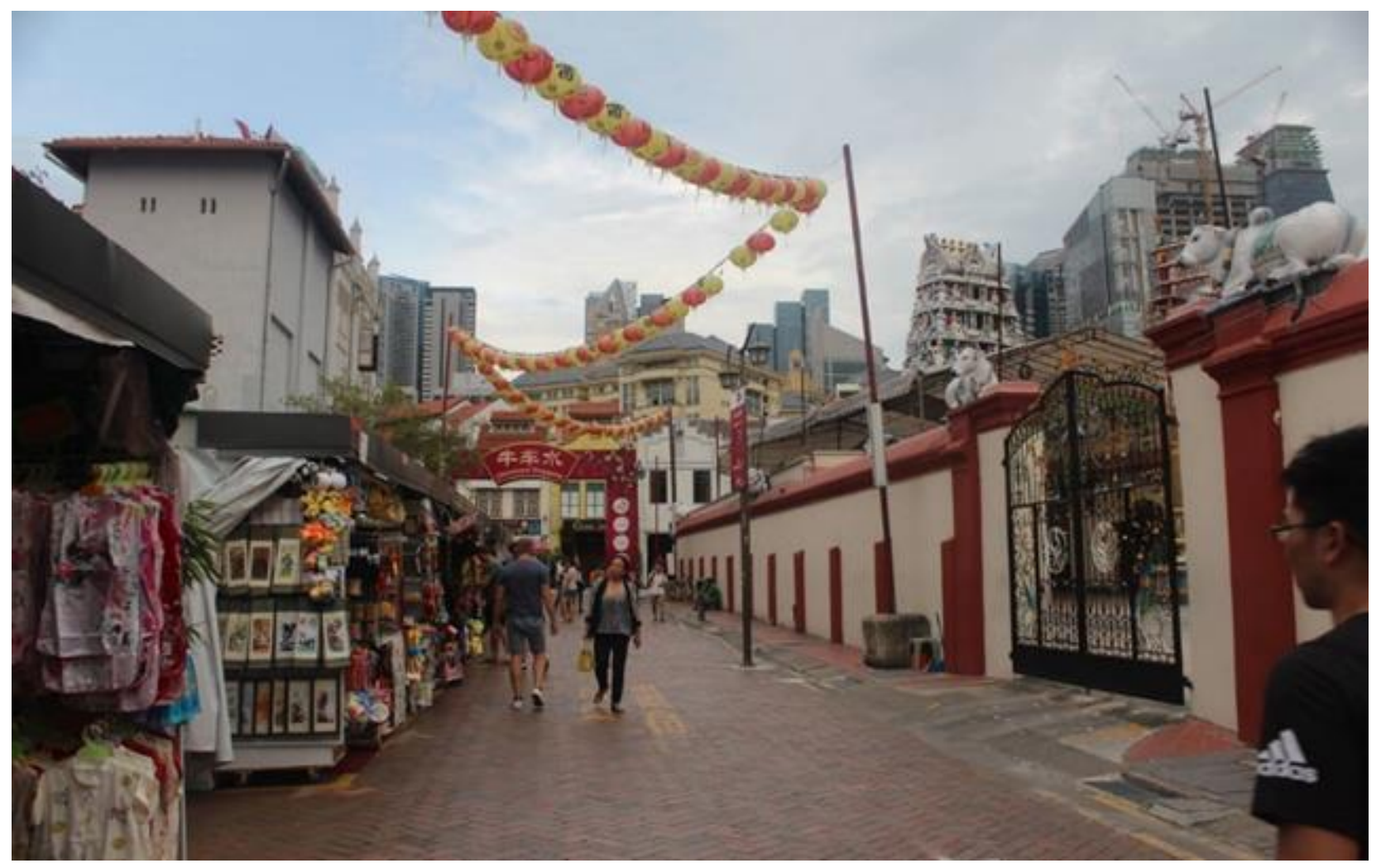

Figure 1: Singapore Chinatown - photograph by Group 1 